\title{
Effect of separate and mixed rearing according to sex on fattening performance and carcass characteristics in Japanese quails (Coturnix coturnix Japonica)
}

\begin{abstract}
The objective of this study was to investigate the effect of sex of Japanese quails (Coturnix coturnix Japonica) on fattening performance and carcass characteristics. The quail chicks were divided into three groups, made up of 96 males or 92 females or 36 individuals of each sex, resulting in a total of 256 chicks. The chicks in the groups were raised using the same feeding regime (24\% CP, $2900 \mathrm{kcal} / \mathrm{kg} \mathrm{ME)}$ and housing conditions for 42 days. There were significant $(\mathrm{P}<0.01)$ differences between male and female groups in weekly live body weight (lbw) gain values on day 35, in average live body weight gain on days 35 and 42, and in lbw gain values between days 14 and 42. Slaughter weight and liver weight were significantly different between groups $(P<0.01)$. The differences between the two sex in mixed group in average body weight gain, average lbw on days 35 and 42, average lbw gain, lbw gain between days 14 and 42, slaughter weight, hot carcass yield, and liver weight were found significant $(\mathrm{P}<0.01)$. Lbw, lbw gain, feed consumption, slaughter weight, hot carcass yield, weights of heart, liver and giblets were higher in female quails while feed conversion rate was lower. As a result, these data suggest that separate raising of male and female Japnese quails might be more advantageous.
\end{abstract}

Key Words: Gender, fatttening performance, slaughter and carcass characteristics, Japanese quails

\section{Zusammenfassung}

Titel der Arbeit: Effekt getrennt geschlechtlicher Mast auf Wachstums- und Schlachtkörpermerkmale bei Wachteln (Coturnix coturnix Japonica)

Es wurde der Einfluss getrennt geschlechlicher Mast auf Wachstums- und Schlachtkörpermerkmale von Wachteln untersucht. Mit insgesamt 256 Wachtelkücken wurden die drei Gruppen mit je 96 männlichen oder 92 weiblichen und einer Gruppe mit je 36 Tieren aus beiden Geschlechtern gebildet. Während der Versuchsdauer von 42 Tagen bestand für sämtliche Gruppen das gleiche Fütterungsregime (24\% Rohprotein, $2900 \mathrm{kcal} \mathrm{ME}$ ). Beim Körpergewicht fanden sich in den einzelnen Versuchswochen signifikante $\left(\mathrm{P}<0.01^{*}\right)$, geschlechterbedingte Unterschiede zwischen den Gruppen in der 35. Woche, bei der täglichen Zunahme in der 35. und 42. sowie bei den Durchschnittszunahmen zwischen der 14. und 42. Woche. Schlacht- und Lebergewichte unterschieden sich ebenfalls zwischen der männlichen und weiblichen Gruppe $\left(^{*}\right)$. In der gemischten Geschlechtergruppe fanden sich Unterschiede bei folgenden Merkmalen zwischen den Geschlechtern: Durchschnittliche tägliche Zunahme, Körpergewicht am 35. und 42. Tag, Körpergewicht am 14. und 35. Tag, Schlachtkörpergewicht, Ausschlachtungs- und Lebergewicht $(*)$. Bei den weiblichen Tieren wurden höhere Körpergewichte, tägliche Zunahme, Futterverbrauch, Schlachtkörper-, Ausschlachtungs-, Herz-, Leber- und Innereiengewichte festgestellt, während die Futterverwertung schlechter war. Aus den Untersuchungen wird abgeleitet, dass eine getrennt geschlechtliche Mast von Wachteln vorteilhaft ist.

Schlüsselwörter: Geschlecht, Mastleistung, Schlacht- und Schlachtkörpermerkmale, Japanische Wachtel

\section{Introduction}

It has been known that fattening performance and carcass characteristics of quails are affected by the lenght of growth period, genotype, selection, nutritional content of the ration used, especially during the growth period. Some researchers reported that body weight and hatching egg weight are correlated (ADEDOKIN and SONAIYA, 2002; 
OZCELIK and OZBEY, 2004) and by selection the body weight could be increasing (MIELENZ et al., 2000; SHAHIN et al., 2000; BRAH et al., 2001).

In addition, gender of quails also play a role on fattening performance and body weight of quail. For example, SHRIVASTAVA et al. (1995) reported that the birds grown as separate had a higher at 5 weeks of age compared to those grown as mixed. At 6 weeks of age, the birds with the highest lbw were males in the mixed-grown group. DU PEREZ and SLAES (1997) reported that female quails reached maximum growth point more delayed than male birds did. Other studies on subject;

OKAMOTO et al. (1989) reported feed conversion rate of 3 different Japanese qual lines as 5.41, 5.41 and 7.54 (g feed/g live weight) for males and 4.38, 4.74 and 5.74 (g feed/g live weight) for female birds.

CERIT and ALTINEL (1998) reported that average lbw at the end of 6 week period was159.01 g in males, $179.79 \mathrm{~g}$ in females (average 169.25). Average total lbw gain in 0-6 weeks period was $167.64 \mathrm{~g}$, feed conversion rate was 3.97 (g/ per bird).

OZCELIK et al. (1998) reported slaughter weight, hot carcass weight, hot carcass yield of 5 week old quails as $111.55 \mathrm{~g}, 73.22 \mathrm{~g}$ and $65.37 \%$ for females, respectively, and $111.38 \mathrm{~g}, 73.29 \mathrm{~g}$ and $65.64 \%$ for males, respectively.

AYASAN et al. (2000) reported at the ed of 5-week period feed conversion rates as 3.51 for females 3.88 for males and 3.72 for mixed-grown group. The researchers concluded that males gain higher body lbw while females had higher carcass weight.

KIRMIZIBAYRAK and ALTINEL (2001) found that at the end of 6-week period slaughter weight as $168.59 \mathrm{~g}$ for males, $213.99 \mathrm{~g}$ for females, carcass weight and carcass yield as $122.11 \mathrm{~g}$ and $72.55 \%$ for males and as $136.46 \mathrm{~g}$ and $64.10 \%$ for female birds.

This study was undertaken to determine the effect of growing males and female Japanese quails separate or mixed together on fattening performance and carcass characteristics.

\section{Materials and Methods}

This study was conducted at the Quail Production and Research Unit of the Department of Zootechny, Faculty of Veterinary Medicine, Firat Univeristy in 2003. A total of 256 quails (Coturnix coturnix Japonica) were used.

Soon after hatching, the chicks were weighed and then placed in mother machine. The temperature of the room was kept at $32-36{ }^{\circ} \mathrm{C}$ for the first 3-4 days and then gradually decrased to room temperature within 10 days. After day 14, no heating was applied. Natural daylight was supplemented with artificial light to give an 24-h photoperiod. Clean drinking water was provided to the birds. On day 14, all chicks were weighed and sex-determination was conducted based on feathering properties and cloaca examination. The birds were divided into 3 groups: female $(n=92)$, male $(n=92)$ and mixed (male $n=36$, female $n=36$ ). The animals in every group were housed in 19x20x22 cm cages with 4 birds per cage. The study was composed of 2 replicates.

All birds were fed ad libitum with a ration containin 24\% CP and $2900 \mathrm{kcal} / \mathrm{kg} \mathrm{ME}$ during the whole study period. Composition of the ration is provided in Table 1.

The 3 treatment groups were female, male, and mixed. Lbw and feed consumption of the birds were determined on weekly basis. Using these data, feed consumption (g), lbw (g), lbw gain (g), and feed conversion rates (g feed/g lbw) were calculated. A 6- 
weeks of age (42 days), a total of 94 quails (29 from female, 27 from male, 19 from mixed) were weighted for slaughter weight and carcass characteristics.

Table 1

Composition and nutritional content of the feed given to the quails (Zusammensetzung und Gehalte der Futtermischung)

\begin{tabular}{lclc}
\hline \multicolumn{1}{c}{$\begin{array}{c}\text { Raw material and feed } \\
\text { additives }\end{array}$} & \% & \multicolumn{1}{c}{$\begin{array}{c}\text { Nutritional } \\
\text { Content }\end{array}$} & \% \\
\hline Maize & 57.072 & Dry matter & 88.23 \\
Sunflower meal & 1.855 & Crude protein (CP) & 24.00 \\
Soybean meal (44 CP) & 35.000 & Crude cellulose & 3.96 \\
Fish meal & 3.888 & Ash & 5.82 \\
Salt & 0.276 & Ether Extract & 2.84 \\
DL-Methionine & 0.084 & Ca & 0.80 \\
Vitamin Premix* & 0.125 & P & 0.40 \\
Mineral Premix** & 0.125 & Methionine & 0.50 \\
Dicalcium Phosphate & 0.690 & Lysine & 1.36 \\
Ground Limestone & 0.885 & Linoleic Acid & 1.27 \\
\hline
\end{tabular}

ME: Metabolisable energy, * : Per $2.5 \mathrm{~kg}$ including; 2.000.000 IU vit. A, 2.000.000 IU vit. $\mathrm{D}_{3}, 35.000 \mathrm{mg}$ vit. E, $4.000 \mathrm{mg}$ vit. $K_{3}, 3.000 \mathrm{mg}$ vit. $B_{1}, 7.000 \mathrm{mg}$ vit. $B_{2}, 5.000 \mathrm{mg}$ vit. $B_{6}, 15 \mathrm{mg} B_{12}, 20.000 \mathrm{mg}$ Niasine,1.000 mg Folicasit, $45 \mathrm{mg}$ Biotine,10.000 mg Cal-D-Pentotenat, $125.000 \mathrm{mg}$ Choline Chlorid and $50.000 \mathrm{mg}$ vit C. **: Per $2.5 \mathrm{~kg}$ including; $60.000 \mathrm{mg}$ Fe, 60.000 mg Zn, 5.000 mg Cu, 1.000 mg I, 200 mg Co, 150 mg Se, 80.000 mg Mn

The data were analyzed according to the following linear model:

$\mathrm{Y}_{\mathrm{ijk}}=\mu+\mathrm{a}_{\mathrm{i}}+\mathrm{b}_{\mathrm{j}}+\mathrm{e}_{\mathrm{ijk}}$

$\mathrm{Y}_{\mathrm{ijk}}$ : the ijk ${ }^{\text {th }}$ observation for each trait

$\mu$ : the population mean

$\mathrm{a}_{\mathrm{i}}$ : the effect of rearing type $(\mathrm{i}=1,2)$

$b_{j}$ : the effect of gender $(j=1,2)$

$\mathrm{e}_{\mathrm{ijk}}$ : the error term $\left(0, \sigma^{2}\right)$

Analysis of Variance (ANOVA) were performed to determine the effects of variables (rearing type and gender) on fattening performance and carcass characteristics of Japanese quails. Means were separated using Duncan's Multiple Range test (SNEDECOR and COCHRAN, 1980). All tests were conducted using SPSS software (SPSS for WINDOWS, 1999).

\section{Results}

Result of ANOVA indicated that both rearing type and gender were significantly effective on means. There was no significant replicate effect.

The average hatching weight of the chicks was $8.25 \pm 0.07 \mathrm{~g}$. At the end of first week at mother machine, the chicks reached to $24.37 \pm 0.71 \mathrm{~g}$. Average lbw, lbw gain, feed consumption, feed conversion rates and slaughter properties, carcass characteristics of the treatment groups between day 14 and 42 are provided in Tables $2-6$. Changes in lbw gain of the groups are demostrated in the Figure.

Significant $(\mathrm{P}<0.01)$ differences were found between separate sex groups in weekly and average lbw gain on day 35 and average lbw on days 35 and 42, and in lbw gain in a period between days 14-42. Slaughter weight, liver weight, were also found significantly different between groups $(\mathrm{P}<0.01)$. In the mix group, the significant 
differences were found between males and females in average lbw on days 35 and 42, in lbw gain, avegare lbw gain, lbw gain in the period of day 14 and 42, slaughter weight, hot carcass yield and liver weight $(\mathrm{P}<0.01)$.

Table 2

Average live body weight of the quailes reared separate or mixed according to the gender (g) (Durchschnittliche Körpergewichte nach Gruppen in den einzelnen Versuchswochen)

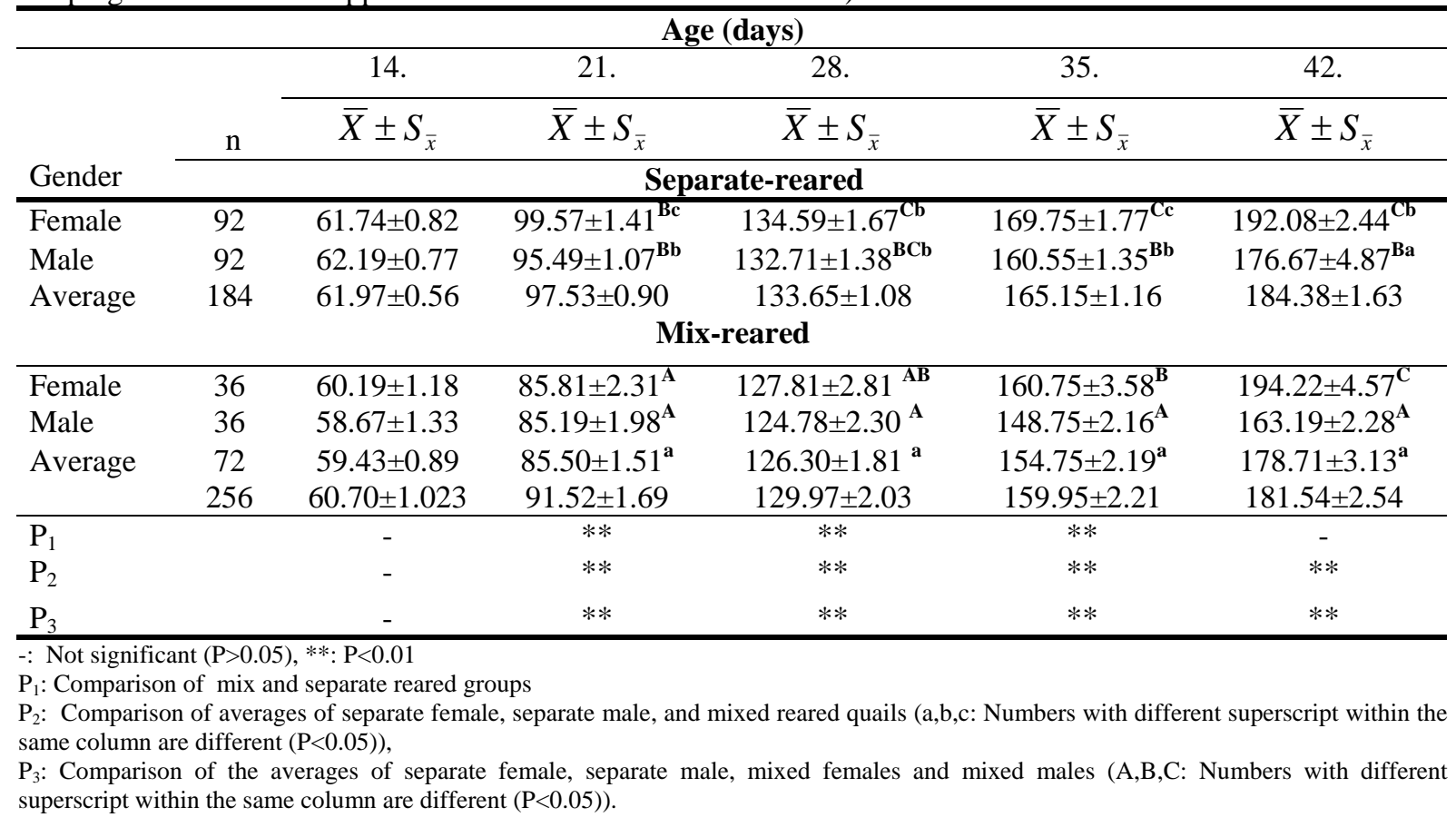

Table 3

Average live body weight gain of the quailes reared separate or mixed according to the gender(g) (Durchschnittliche tägliche Zunahme nach Gruppen in den einzelnen Versuchswochen)

\begin{tabular}{|c|c|c|c|c|c|c|c|}
\hline \multicolumn{8}{|c|}{ Age (days) } \\
\hline \multirow{3}{*}{ Gender } & \multirow[t]{2}{*}{$\mathrm{n}$} & 21. & 28. & 35 & 42. & $\begin{array}{l}\text { Average live } \\
\text { body weight } \\
\text { gain (g) }\end{array}$ & $14-42$ \\
\hline & & $\bar{X} \pm S_{\bar{X}}$ & $\bar{X} \pm S_{\bar{X}}$ & $\bar{X} \pm S_{\bar{X}}$ & $\bar{X} \pm S_{\bar{X}}$ & $\bar{X} \pm S_{\bar{x}}$ & $\bar{X} \pm S_{\bar{X}}$ \\
\hline & \multicolumn{7}{|c|}{ Separate-reared } \\
\hline Female & 92 & $37.82 \pm 1.33^{\mathrm{BC}}$ & $35.03 \pm 1.49^{\mathrm{Aa}}$ & $35.15 \pm 2.13^{\mathbf{C b}}$ & $22.33 \pm 2.23^{\text {Aab }}$ & $32.58 \pm 0.58^{\mathbf{C b}}$ & $130.34 \pm 2.30^{\mathrm{Cb}}$ \\
\hline Male & 92 & $33.30 \pm 1.18^{\mathbf{B b}}$ & $37.22 \pm 1.42^{\text {ABab }}$ & $27.85 \pm 1.32^{\mathrm{ABa}}$ & $16.12 \pm 2.01^{\text {Aa }}$ & $28.62 \pm 0.47^{\text {Ba }}$ & $114.49 \pm 1.88^{\mathrm{Ba}}$ \\
\hline \multicolumn{8}{|c|}{ Mix-reared } \\
\hline Female & 36 & $25.61 \pm 2.05^{\mathrm{A}}$ & $42.00 \pm 1.31^{\mathrm{B}}$ & $32.94 \pm 1.74^{\mathrm{BC}}$ & $33.47 \pm 3.54^{\mathrm{B}}$ & $33.51 \pm 1.01^{\mathrm{C}}$ & $134.03 \pm 4.05^{\mathrm{C}}$ \\
\hline Male & 36 & $26.53 \pm 1.57^{\mathrm{A}}$ & $39.58 \pm 0.90^{\mathbf{A B}}$ & $23.97 \pm 2.12^{\mathrm{A}}$ & $14.44 \pm 2.23^{\mathrm{A}}$ & $26.13 \pm 1.01^{\mathrm{A}}$ & $104.53 \pm 2.20^{\mathbf{A}}$ \\
\hline \multirow[t]{2}{*}{ Average } & 72 & $26.07 \pm 1.28^{\mathrm{a}}$ & $40.79 \pm 0.80^{\mathbf{b}}$ & $28.46 \pm 1.46^{\mathrm{a}}$ & $23.96 \pm 2.37^{\mathbf{b}}$ & $29.82 \pm 0.72^{\mathrm{a}}$ & $119.28 \pm 2.88^{\mathrm{a}}$ \\
\hline & 256 & $30.82 \pm 1.53$ & $38.46 \pm 1.27$ & $29.98 \pm 1.83$ & $21.59 \pm 2.56$ & $30.21 \pm 0.77$ & $120.85 \pm 1.40$ \\
\hline $\mathrm{P}_{1}$ & & $* *$ & $* *$ & - & - & - & - \\
\hline $\mathrm{P}_{2}$ & & $* *$ & * & ** & $*$ & $* *$ & $* *$ \\
\hline $\mathrm{P}_{3}$ & & $* *$ & $*$ & ** & $* *$ & $* *$ & $* *$ \\
\hline
\end{tabular}

The differences between separate-female and mix females were found significant in average lbw on days 21, 28, and 35, in lbw gain on days 21,28 , and 42 and in hot 
carcass yield $(\mathrm{P}<0.05, \mathrm{P}<0.01)$. The difference between separate and mixed males were significant in average lbw gain on days 21, 28, 35 and 42, in lbw gain on day 21, lbw gain from days 14 to $42(\mathrm{P}<0.01)$. There was no significant difference in carcass characteristics for this group.

Table 4

Average feed consumption of the quails reared separate or mixed according to the gender (g) (Durchschnittlicher Futterverbrauch nach Gruppen in den einzelnen Versuchswochen)

\begin{tabular}{|c|c|c|c|c|c|c|}
\hline \multicolumn{7}{|c|}{ Age (days) } \\
\hline \multirow{3}{*}{ Gender } & & 21. & 28. & 35. & 42. & $14-42$ \\
\hline & $\mathrm{n}$ & $\bar{X} \pm S_{\bar{X}}$ & $\bar{X} \pm S_{\bar{X}}$ & $\bar{X} \pm S_{\bar{X}}$ & $\bar{X} \pm S_{\bar{X}}$ & $\bar{X} \pm S_{\bar{X}}$ \\
\hline & \multicolumn{6}{|c|}{ Separate-reared } \\
\hline Female & 92 & $110.66 \pm 3.34$ & $157.51 \pm 5.21$ & $175.66 \pm 10.82$ & $155.45 \pm 16.05$ & $599.28 \pm 18.05$ \\
\hline Male & 92 & $97.40 \pm 4.83$ & $146.97 \pm 7.36$ & $166.09 \pm 8.06$ & $126.77 \pm 12.50$ & $537.23 \pm 19.19$ \\
\hline \multirow[t]{2}{*}{ Average } & 184 & $104.03 \pm 2.91$ & $152.24 \pm 4.53$ & $170.88 \pm 6.71$ & $141.11 \pm 10.28$ & $568.26 \pm 13.59$ \\
\hline & \multicolumn{6}{|c|}{ Mix-reared } \\
\hline \multirow[t]{2}{*}{ Female- } & 72 & $112.97 \pm 5.93$ & $137.16 \pm 3.99$ & $156.31 \pm 5.04$ & $131.25 \pm 16.04$ & $537.68 \pm 21.39$ \\
\hline & 256 & $107.01 \pm 2.26$ & $147.21 \pm 3.53$ & $166.02 \pm 5.06$ & $137.82 \pm 8.61$ & $558.06 \pm 11.54$ \\
\hline
\end{tabular}

Table 5

Feed conversion rates of the quails reared separate or mixed according to the gender (g feed/ g live weight) (Futterverwertung nach Gruppen in den einzelnen Versuchswochen)

\begin{tabular}{lcccccc}
\hline \multicolumn{7}{c}{ Age (days) } \\
\hline \multirow{2}{*}{ Gender } & & $14-21$ & $22-28$ & $29-35$ & $36-42$ & $14-42$ \\
\cline { 2 - 7 } & $\mathrm{n}$ & $\bar{X} \pm S_{\bar{x}}$ & $\bar{X} \pm S_{\bar{x}}$ & $\bar{X} \pm S_{\bar{x}}$ & $\bar{X} \pm S_{\bar{x}}$ & $\bar{X} \pm S_{\bar{x}}$ \\
\cline { 2 - 7 } & 92 & $2.9 .3+0.44$ & $4.50+0.35$ & $5.00+0.51$ & $6.96+0.77$ & $4.60+0.19$ \\
Female & 92 & $2.93 \pm 0.61$ & $3.95 \pm 0.25$ & $5.96 \pm 0.54$ & $7.86 \pm 0.70$ & $4.69 \pm 0.15$ \\
Male & 184 & $2.93 \pm 0.37$ & $4.23 \pm 0.22$ & $5.48 \pm 0.37$ & $7.41 \pm 0.52$ & $4.65 \pm 0.12$ \\
Average & 72 & $4.33 \pm 0.42$ & $3.36 \pm 0.24$ & $5.49 \pm 0.45$ & $5.48 \pm 0.96$ & $4.51 \pm 0.17$ \\
& 256 & $3.40 \pm 0.29$ & $3.94 \pm 0.18$ & $5.48 \pm 0.29$ & $6.77 \pm 0.46$ & $4.60 \pm 0.10$ \\
\hline Female- & \multicolumn{7}{c}{ Separate-reared }
\end{tabular}

When the gender was not taken in to account, significant $(\mathrm{P}<0.05, \mathrm{P}<0.01)$ differences were found between separate grown and mixed-grown groups in average lbw on days 21,28 , and 35 in lbw gain on days 21 and 28, in feed conversion rates on days 21, 28 and 42 but no difference was found in carcass characteristics.

No significant difference was found in feed consumption between separate-grown males and mix grown male and females $(\mathrm{P}>0.05)$.

Average slaughter weight, hot carcass yield, hearth weight, liver, giblet weights in separate grown quails were $176.80 \mathrm{~g}, 121.82 \mathrm{~g}, 69.66$ \%, $1.86 \mathrm{~g}, 4.91 \mathrm{~g}$ and $4.38 \mathrm{~g}$, respectively. Corresponding numbers for mix-grown group were $179.63 \mathrm{~g}, 119.68 \mathrm{~g}$, $67.23 \%, 1.84 \mathrm{~g}, 4.93 \mathrm{~g}$ and $4.27 \mathrm{~g}$, respectively. 
Table 6

Some carcass characteristics of the the quails reared separate or mixed according to the gender as determined on day 42 after slaughter (Schlachtmerkmale der Wachteln nach Gruppen bei Schlachtung am 42. Tag)

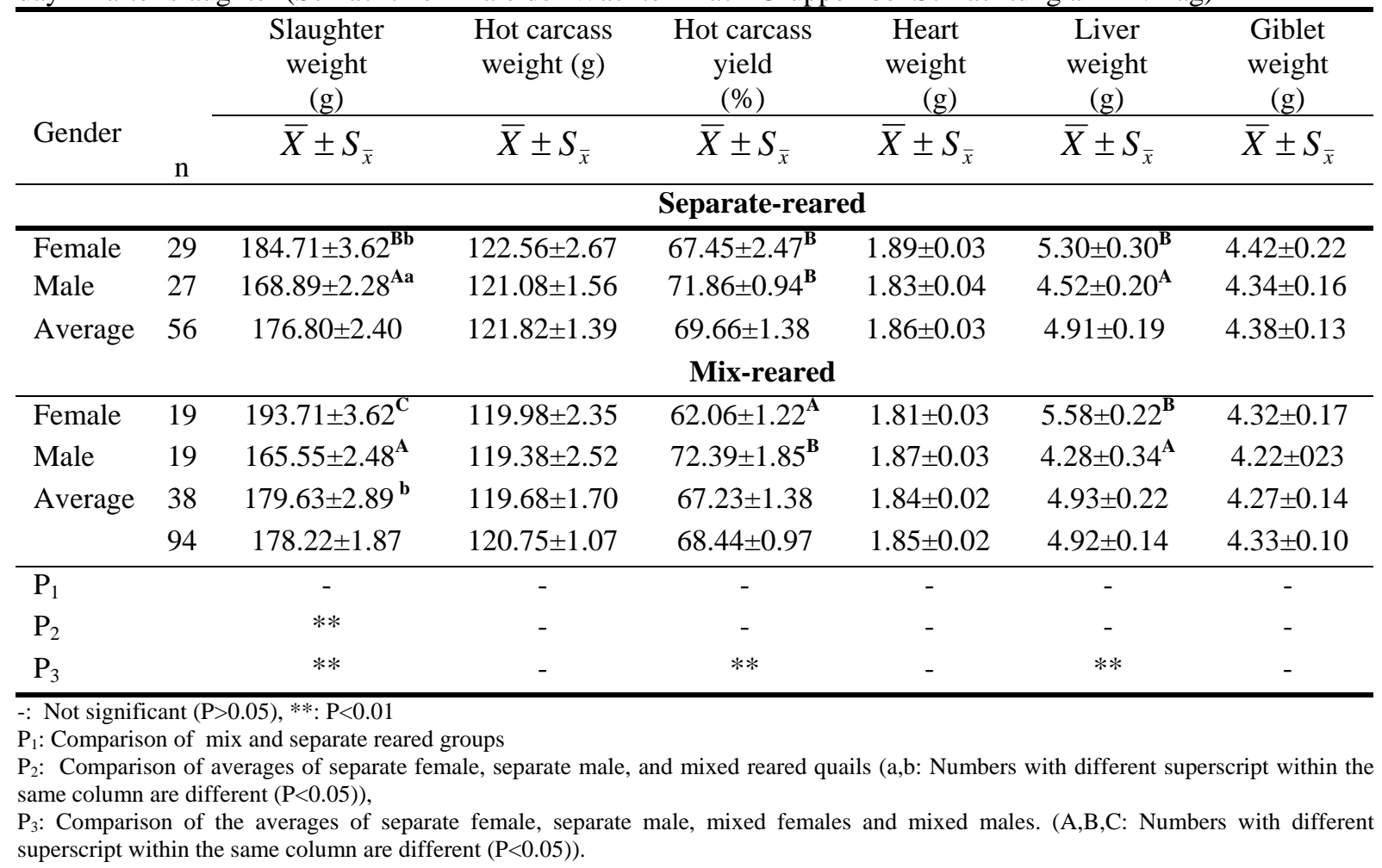

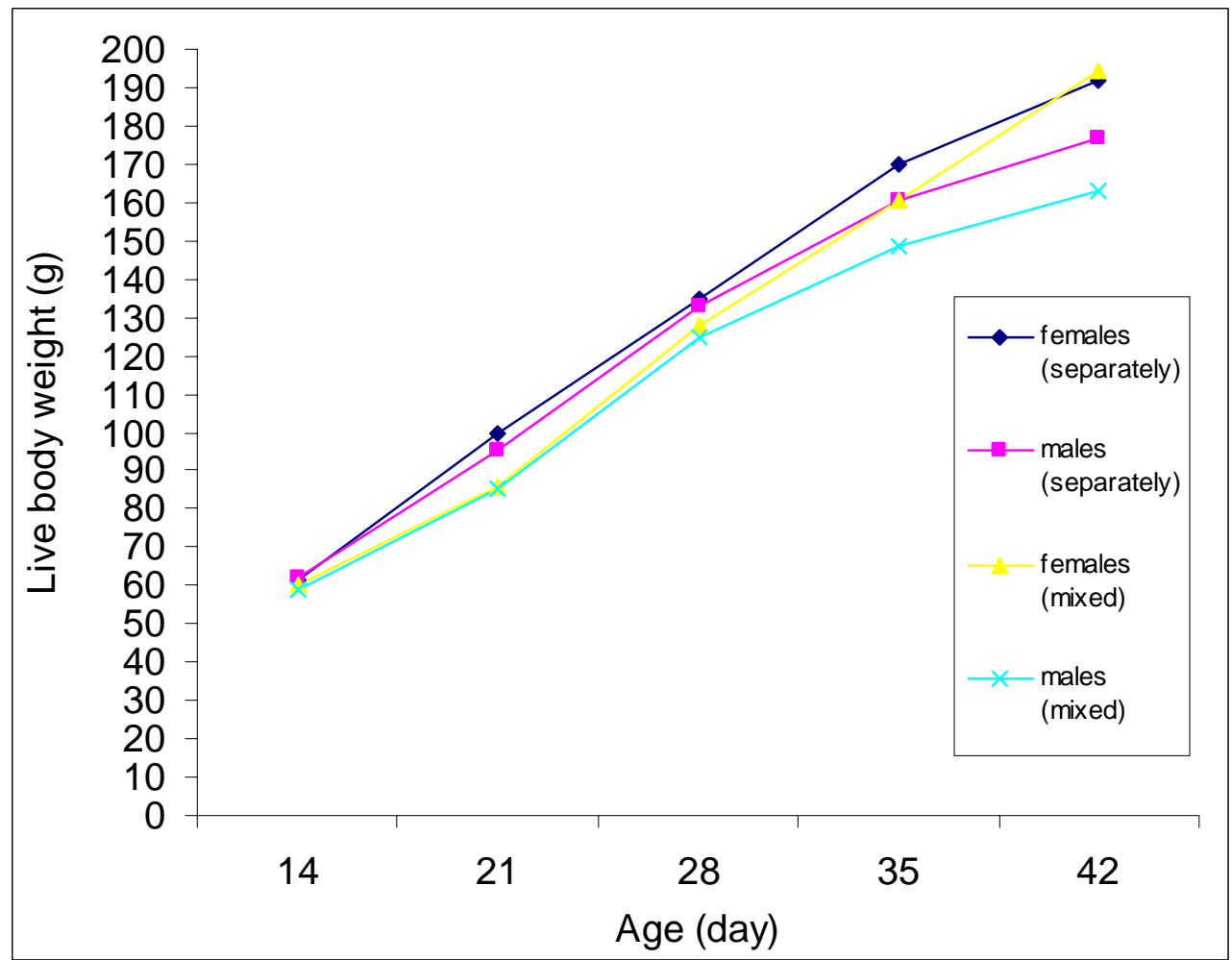

Figure: Changes of live body weight of quails according to age (Körpergewichte der Wachteln nach Geschlecht abhängig vom Alter in den Versuchsgruppen) 


\section{Discussion}

Live body weight of the birds in separate-grown group were found significantly higher between days 21 and 35 than those quails in mixed grown group. On day 42, however, lbw in separate group was still higher but not significantly. During the study, regardless of mixed or separate housing, female birds had higher body weight than male birds. This finding is consistent with the results by SHRIVASTAVA et al. (1995) and DU PEREZ and SLAES (1997).

Female birds had a higher average lbw than the male quails did. The highest lbw-gain was observed in separate-male mixed-female groups. The difference between mix and separate males was significant. The average lbw-gain in mix and separate groups were not significantly different despite a higher average found in separate group. Our finding that females gained more body weight than the male quails did is consistent with the results of some previous studies (AYASAN et al., 2000). In addition, the highest lbw-gain seen in either sex group in rearing period of days 14-28 was also similar to those reported by AYASAN et al. (2000). Our results, however, were not in agreement with those of SHRIVASTAVA et al. (1995) who reported that the highest lbw was seen in mixed-male and separate-female quail groups.

In general, female quails consumed more feed in all weeks compared to the male birds. Average feed consumption of mix-reared and separate-reared were not significantly different despite a lower feed consumption found in mix group. These results were consistent with the findings reported by AYASAN et al. (2000).

Feed conversion rates were lower in female quails than male quails, and in mix-reared bird than in separate-reared birds. Lower feed conversion rate of female quails was reported in previous reports (OKAMOTO et al., 1989; AYASAN et al., 2000).

Regardless of mix or separate rearing, slaughter weight and hot carcass weight of female quails were higher than those of male birds. These differences were significant for slaughter weight but not for hot carcass weight. Hot carcass yield was higher in males than in females. In general, there results were as expected. It has been reported that male quails reach sexual maturation on day 36 while females do on day 42 (KOCAK, 1985). Reaching sexual maturity, fattening occurs more rapidly and extensively in females due to female hormones resulting in a higher lbw compared to the male quails. The finding that a higher live-slaughter weight and carcass weight in females compared to male quails has been supported by many studies (AYASAN et al., 2000; KIRMIZIBAYRAK and ALTINEL, 2001). Despite lower lbw, a higher hot carcass yield seen in male birds might be explained by larger bones (KOCAK, 1985) and lighter internal organs of the males compared to those of female birds. These results are also consistent with the previous reports (OZCELIK et al., 1998; KIRMIZIBAYRAK and ALTINEL, 2001) .

In general, weights of heart, liver and giblet were found higher in females than those in males. However, this difference was only significant for the liver weight. Heavier internal organs of female birds resulted in an increased slaughter weight and hot carcass weight. OZCELIK et al. (1998) and AYASAN et al. (2000) reported similar findings. Contradictory to the results of the present study, OZCELIK et al. (1998) reported a higher carcass weight in males than in females. This discrepancy might be due to differences in stocking-caring conditions as well as limiting the rearing period with 5-weeks in the a fore mentioned study. 
In conclusion, our results revealed that the effect of sex on lbw, lbw-gain, slaughter weight, carcass weight was significant. In females, lbw, lbw-gain, feed consumption, slaughter weight, hot carcass weight, liver-hearth-giblet weights were found higher where as feed conversion rate was lower. These results suggest that rearing male and female quails separately can be recommended to the producers for a higher lbw, lbwgain, and carcass weight.

\section{References}

ADEDOKIN, S.A.; SONAIYA, E.B.:

Crossbreeding Nigeria Indigenous with Dahlem Red chickens for improved productivity and adaptability. Arch. Tierz., Dummerstorf 45 (2002) 3, 297-305

AYASAN, T.; BAYLAN, M.; ULUOCAK, A.N.; KARASU, O.:

Effects of sex and different stocking densities on the fattening characteristics of Japanese quails. Journal of Poultry Research. 2 (2000) 1, 47-50

BRAH, G.S.; CHAUDHARY M.L; SANDHU, J.S.:

Direct and correlated responses to selection for 4-week body weight in two lines of Japanese quails. Arch. Tierz., Dummerstorf 44 (2001) 1, 99-108

DU PEREZ, J.J.; SLAES, J.:

Growth rate of different sexes of the European quail (Coturnix Coturnix). British Poultry Science. 38 (1997), 314-315

KIRMIZIBAYRAK, T.; ALTINEL, A.:

Some parameters about the important yield characters of Japanese quails (Coturnix coturnix japonica). J. Fac. Vet. Med. Univ. Istanbul. 27 (2001) 1, 309-328

KOCAK, C.:

Quail production. Aegean Zootechny Association publications. No: 1, Bilgehan Pres., Izmir, Turkey; (1985)

MIELENZ, N.; DITMAR, E.; SCHÜLER, L.:

Effektivität der Zuchtwertschätzung mit transformierten Daten, überprüft mit Mütter-Tochter-Paaren eines Wachstumsexperimentes (Effectiviness of genetic evaluation eith transformed data by using damdaughter pairs of Japanese quails). Arch. Tierz., Dummerstorf 43 (2000) 3, 299-309

OKAMOTO, S.; NAGATA, S.; KOBAYASHI, S.; MATSUO, T.:

Effects of photoperiod and cage density on growth and feed conversion in large and small quail lines selected for body weight. Japanese Poultry Sci., 26 (1989) 3, 150-156

OZCELIK, M.; OZBEY O.:

The effect of the high environmental temperature on some blood parameters and the laying performance of Japanese quails with different body weights. Arch. Tierz., Dummerstorf 47 (2004) 1, 93-98

OZCELIK, M.; POYRAZ, O.; AKINCI, Z.:

The effect of sex on slaughter and carcass characteristics in quails, Firat University J. of Institute of Health Science. 12 (1998) 2, 133-139

SHAHIN, K.A.; SHEMEIS, A.R.; ABDALLAH, O.Y.; SALEH, K.:

Selection index alternatives for increases marketing, body weight with minimum concomitant reduction in body bone percentage-recourse to tissue dissection on Japanese quail. Arch. Tierz., Dummerstorf $\mathbf{4 3}$ (2000) 5, 535-543

SHRIVASTAVA, S.K.; AHUJA, S.D.; BANDYOPADHYAY, U.K.; SINGH, R.P.:

Influence of rearing mixed and separate sexes on growth performance and carcass yield of Japanese quail. Indian Journal of Poultry Science. 30 (1995) 2, 158-160

SNEDECOR, G.W.; COCHRAN, W.G.:

Statistical Method. Seventh Edition. The Iowa State University Pres. Ames, Iowa, U.S.A., (1980)

SPSS for WINDOWS.:

Release 9.0. Standard version. Copyright SPSS Inc., (1999)

Received: 2005-11-29

Accepted: 2006-07-31

Corresponding Author

Associate Prof. Dr. İBRAHIM ŞEKER, Department of Zootechny, Faculty of Veterinary

Medicine, Firat University, 23119 ELAZIG, TURKEY

E-Mail: iseker@firat.edu.tr, iseker52@gmail.com 